\title{
The growing role of gene methylation on endocrine function
}

\author{
Verónica García-Carpizo, Lidia Ruiz-Llorente, Mario Fraga ${ }^{1,2}$ and Ana Aranda \\ Instituto de Investigaciones Biomédicas, Consejo Superior de Investigaciones Científicas and Universidad Autónoma de Madrid, Arturo Duperier 4, 28029 Madrid, Spain \\ ${ }^{1}$ Centro Nacional de Biotecnología, Consejo Superior de Investigaciones Científicas (CNB-CSIC), Madrid, Spain \\ ${ }^{2}$ Instituto Universitario de Oncología del Principado de Asturias (IUOPA), Universidad de Oviedo, Oviedo, Spain \\ (Correspondence should be addressed to A Aranda; Email: aaranda @iib.uam.es)
}

\begin{abstract}
DNA methylation is the best studied epigenetic factor, playing a key role in producing stable changes in gene expression, thus defining cell identity and function and adapting cells to environmental changes. DNA methylation has also been recently shown to mediate cell responses to physiological endocrine signals. Moreover, alterations of the normal DNA methylation pattern can also contribute to the development of endocrine and metabolic diseases and can explain the relationship between an individual's genetic background, the environment, and disease. It should be remarked that although DNA methylation and demethylation are active processes, epigenetic changes produced during development can impact adult processes, establishing the idea that endocrine function can be persistently affected by events occurring in early life. Given the complexity of the endocrine system, both genetic and epigenetic processes, including DNA methylation, must be involved in its proper development and functioning. In this study, we summarize the recent knowledge in the field of DNA methylation and endocrinology. Given that DNA methylation can be involved in a number of endocrine and metabolic disorders, understanding and manipulating this modification opens a new door for preventing and treating endocrine diseases.
\end{abstract}

Journal of Molecular Endocrinology (2011) 47, R75-R89

\section{What is epigenetics?}

The term 'epigenetics' has classically been used to explain phenotypic events that cannot be described by genetic mechanisms. Waddington (1942) coined the term 'epigenetics' in the 1940s, defining epigenetics as 'the branch of biology that studies the causal interactions between genes and their products, which bring the phenotype into being'. An updated definition now considers epigenetic conditions to be those that affect gene expression without changing the nucleotide sequence, in a way that can involve mitotic, or, less frequently, meiotic inheritance (Holliday 2006), conferring a certain stability on epigenetic events through cell generations. Very recently, Skinner et al. (2010) have defined epigenetics as "molecular factors and processes around DNA that are mitotically stable and regulate genome activity independent of DNA sequence'. Although most of the cells in a multicellular organism share the same genetic information, an organism produces many different cell types during its development, each characterized by a typical gene expression profile and by specific functions. Consequently, cell differentiation might be considered as a largely epigenetic phenomenon. The first epigenetic modification identified was DNA methylation in the 1970s (Holliday \& Pugh 1975). However, epigenetics also addresses covalent modifications of histones and the mechanisms through which they alter chromatin structure (Turner 1998). Other gene regulation mechanisms such as non-coding RNA are also included among epigenetic pathways (Aguilera et al. 2010). Epigenetic processes are likely to be expanded in the future. For example, the recent identification of hydroxymethylcytosine residues is a new epigenetic mark whose function remains to be elucidated (Kriaucionis \& Heintz 2009). In this review, we will focus on only one of these epigenetic modifications, namely DNA methylation.

\section{DNA methylation}

DNA methylation is the most extensively investigated epigenetic modification because more than two decades ago it was shown to play a critical role in cancer. Feinberg \& Vogelstein (1983) demonstrated for the first time that tumor cells can lose DNA methylation

DOI: 10.1530/JME-11-0059 Online version via http://www.endocrinology-journals.org 
at specific DNA regions. Subsequently, many laboratories identified a number of tumor suppressor genes that often become aberrantly hypermethylated and repressed in cancer cells (Feinberg 2007). Later on, investigations moved outside of the cancer field and today it is well established that DNA methylation is essential for normal development and differentiation in mammals (Fraga 2009). DNA methylation consists of the covalent addition of a methyl group at the 5-position of cytosines. This normally occurs on a cytosine followed by a guanine, called a CpG dinucleotide. This dinucleotide normally occurs at low frequency in vertebrate DNA. However, stretches of DNA with a high $\mathrm{C}+\mathrm{G}$ content and a high frequency of CpG dinucleotides relative to the bulk genome have been defined as CpG islands by Gardiner-Garden \& Frommer (1987). Most CpG dinucleotides are methylated, but those located in $\mathrm{CpG}$ islands are usually unmodified. Although $\mathrm{CpG}$ islands are located preferentially in gene promoters or regulatory regions, most of these dinucleotides are nonetheless found in repetitive DNA elements. The DNA methylation pattern is removed in the early embryo and then reconstituted at the time of implantation (Kafri et al. 1992). DNA methylation is also responsible for genomic imprinting, securing monoallelic gene expression by repressing expression of the paternal or maternal genes, for X-chromosome inactivation in females, and for silencing of parasitic elements (Payer \& Lee 2008, Kacem \& Feil 2009).

Although methylation of cytosine bases (mCs) in CpG dinucleotides is the principal form of DNA methylation, other modifications such as methylation of cytosine in $\mathrm{CpNpG}$ trinucleotides (where $\mathrm{N}$ denotes any base) or hydroxymethyl cytosines (hmCs) also exist, and all these modifications define the DNA methylome of a cell. A full methylome analysis should include these modifications in addition to mCG, although the biological function of mCGs and hmCs has not yet been clarified (Beck 2010). Methylome analysis, as well as the analysis of other epigenetic marks, will be needed to define the epigenome map characteristics of normal development and differentiation, including development of endocrine glands, and for the identification of genomic regions involved in endocrine and nonendocrine disorders. Another unresolved issue in DNA methylation is that of bisulfite sequencing, the currently used method of analysis that relies on the conversion of unmethylated cytosine residues to uracil cannot distinguish between methylation and hydroxymethylation, and densely hydroxymethylated regions of DNA may be underrepresented in quantitative methylation analyses (Huang et al. 2010). In 2009, the first genome-wide, single-base resolution maps of methylated cytosines in a mammalian genome have been resolved (Lister et al. 2009). Surprisingly, and in contrast with differentiated cells, a significant fraction (almost one-quarter) of the methylation found in embryonic stem cells occurred in a non-CG context. This modification was lost on induction of differentiation and was restored in induced stem cells. These interesting results provide a foundation for future studies exploring this key epigenetic modification in human disease and development and to analyze its role in endocrine function.

\section{DNA methyltransferases (DNMTs): hormonal control of DNMT expression}

S-adenosylmethionine acts as a methyl donor for addition of the methyl group to cytosine residues within CpG dinucleotides. This reaction is catalyzed by DNA methyltransferase (DNMT) enzymes. In mammals, DNMTs include four members, in two families that are structurally and functionally distinct. The DNMT3 family establishes the initial CpG methylation pattern, whereas DNMT1 maintains this pattern during DNA replication (Mortusewicz et al. 2005, Chen \& Li 2006). The DNMT3 family has three members: DNMT3A, DNMT3B, and DNMT3L (DNMT3 like). DNMT3L does not have enzymatic activity but may function as a regulator of DNA methylation. Inactivation of DNMT1, DNMT3A, and DNMT3B by gene targeting was found to cause lethality in mice, either pre- or post-natally. DNMT3A and DNMT3B act basically as de novo methyltransferases establishing the DNA methylation patterns at early developmental stages, although they have also a function at later stages maintaining global DNA methylation levels. In contrast, DNMT1 lacks de novo methyltransferase activity but serves as a maintenance for methyltransferase by copying the DNA methylation pattern from the parental strand to the daughter strand after DNA replication (Robertson 2005; Fig. 1).

Recent results suggest that DNMT expression is under hormonal control. For instance, DNMT3A, DNMT3B, and DNMT1 are under the regulation of female sex steroid hormones during the menstrual cycle (Yamagata et al. 2009, van Kaam et al. 2011), and aberrant expression of DNMTs was observed in endometriosis (Wu et al. 2007, van Kaam et al. 2011). On the other hand, estradiol increases DNMT3A and DNMT3B expression in the dorsal hippocampus, and increased methylation of memory suppressor genes (e.g. reelin) may be crucial for estradiol to enhance memory consolidation (Zhao et al. 2010). Paradoxically, even though congenital hypothyroidism is associated with impaired cognitive development, increased methylation of the reelin and $B D N F$ genes is also found in the hippocampus of hypothyroid rats (Sui \& Li 2010), showing the complex effects of thyroid hormones in brain development. 


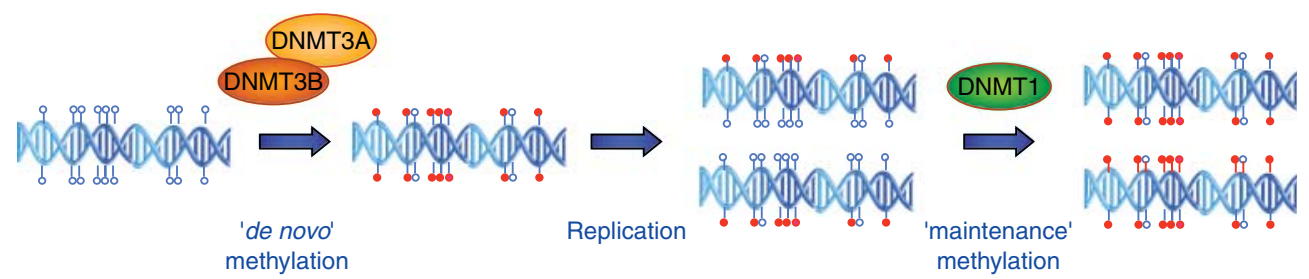

Figure 1 The DNA methyltransferases DNM3A and DNMT3B are responsible for de novo methylation, whereas DNMT1 is in charge of maintaining methylation after DNA replication by modifying the daughter strand. The daughter strands of DNA following replication are unmethylated. Hemi-methylation status is recognized by DNMT1, which is recruited to the replication fork, and then restores the parental methylation pattern. Unmethylated CpGs are shown by empty circles and the methylated nucleotides by red circles.

Alterations in male reproductive tract development and postpubertal prostatitis observed after exposure to the antiandrogenic compound vinclozolin during gonadal sex determination could also be related to changes in DNMTs expression in the testis and prostate (Anway \& Skinner 2008, Anway et al. 2008, Cowin et al. 2010). Furthermore, changes in DNMT1 expression have been shown to contribute to both prostate cancer initiation and promotion (Esteller 2005, Feinberg et al. 2006).

Peptide hormones can also regulate DNMT expression. For instance, autocrine human GH (hGH) increases expression of DNMT1, DNMT3A, and DNMT3B in mammary carcinoma cells and it has been postulated that the oncogenic effects of hGH in these cells is secondary to the increase in DNMTs that in turn causes silencing of the plakoglobin gene by hypermethylation of its promoter CpG island (Shafiei et al. 2008).

Although DNMT expression and function can be regulated by hormones, the cited studies show mostly correlative effects and the molecular mechanisms involved are still poorly understood.

\section{Gene repression by DNA methylation: link to histone modifications}

In general, DNA methylation leads to repression of gene expression. Normally, methylated genes are either not transcribed into mRNA or transcribed at a markedly reduced rate (Esteller 2005, Feinberg et al. 2006). Cytosine methylation alters the structure of the major groove of DNA, and this can block the recruitment of transcription factors to their binding sites and inhibit gene transcription. However, although DNA methylation can affect association of several transcription factors (including E2F, MLTF, or CTCF) to their recognition sites, other transcription factors, such as Sp1, can still bind to methylated DNA. In addition to altering transcription factor binding, DNA methylation allows the recruitment of proteins with high affinity for methylated CpGs (methyl binding proteins or MBDs) that can repress gene expression. Five MBDs have been identified (MeCP2, MBD1, MBD2, MBD3, and MBD4), and excluding MBD4, they induce transcriptional silencing (Bird \& Wolffe 1999). Histone deacetylation is linked to chromatin compaction and transcriptional repression, and after binding to methylated CpG dinucleotides, the MBD MeCP2 interacts with corepressor complexes containing histone deacetylases (HDACs) and Sin3a inducing gene silencing (Jones et al. 1998, Nan et al. 1998). Interestingly, the same corepressor complexes are recruited to hormone nuclear receptors and mediate ligand-independent repression of gene expression by some unliganded non-steroid receptors and by antagonist-bound steroid receptors (Aranda \& Pascual 2001). Other MBDs interact directly with DNMT1 and with one or more HDACs (Fuks et al. 2000, 2001, Robertson et al. 2000, Rountree et al. 2000, Aapola et al. 2002, Kimura \& Shiota 2003), suggesting the existence of a functional cooperation between CpG methylation and histone deacetylation that silences gene expression in a stable manner.

The N-terminal tails of histones can undergo different posttranslational modifications that seem to have a crucial influence on chromatin structure and are linked to either transcriptional repression or activation (Kouzarides 2007). Whereas histone acetylation is normally associated with transcriptionally active chromatin, methylation of histone $\mathrm{H} 3$ at particular residues can lead to local formation of heterochromatin, which in contrast with DNA methylation that causes stable transcriptional repression is fully reversible. The existence of a cross talk between DNA methylation and histone modifications, which can be mediated by interactions between histone methyltransferases and DNMTs, has been recently demonstrated (Fig. 2). Relationships between DNA methylation and histone modification have implications for understanding normal development as well as somatic cell reprogramming and tumorigenesis (Cedar \& Bergman 2009). Thus, histone deacetylation facilitates methylation of H3K9 by the histone methyltransferase G9a. Methylation of this residue facilitates the recruitment of the 

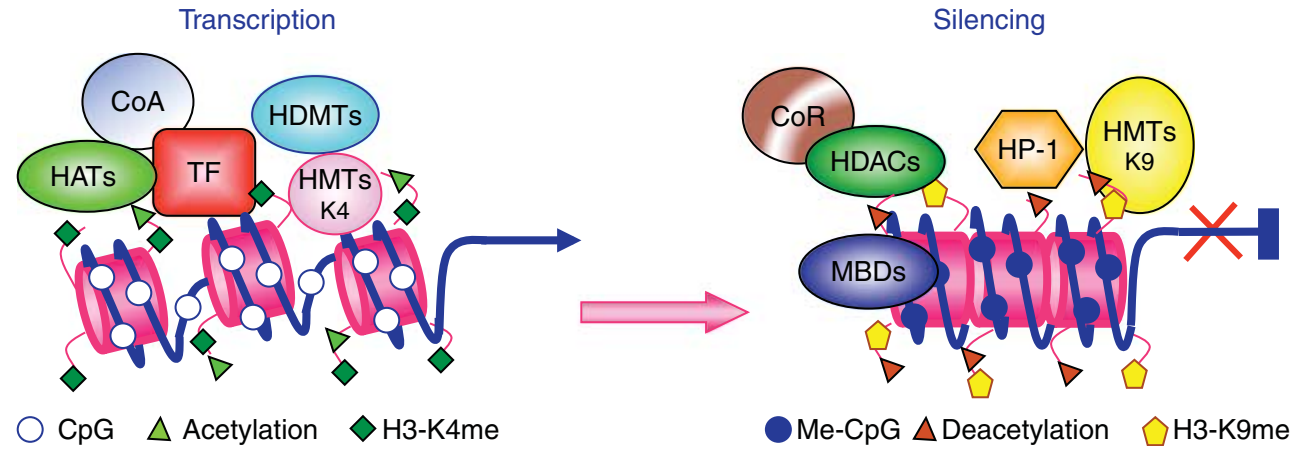

Figure 2 DNA methylation causes gene silencing. Transcriptionally active chromatin is characterized by unmethylated DNA and binding of transcription factors (TF) with recruitment of coactivators (CoA) and histone-modifying enzymes such as histone acetyltransferases (HATs), methyltransferases (HMTs), and demethylases (HDMTs), which induce among other modifications of histone acetylation and $\mathrm{H} 3$ di- or tri-methylation in lysine 4 (H3-K4me, a marker of active chromatin). CpG methylation (Me-CpG) silences gene expression by recruitment of methyl-binding proteins (MBDs), the heterochromatin protein HP-1, corepressor (CoR) complexes containing histone deacetylases (HDACs), and histone methyltransferases leading to deacetylation of the histone tails and methylation of $\mathrm{H} 3$ in lysine 9 (H3-K9me). These silencing complexes produce chromatin compaction. Many other epigenetic factors are also known to control gene transcription and silencing and therefore this figure illustrates only an example of regulation of gene expression.

heterochromatin protein 1 (HP1), allowing local heterochromatinization. The histone methyltransferase G9a also recruits DNMT3A and DNMT3B, inducing de novo DNA methylation, at the final step of silencing of pluripotency genes (Feldman et al. 2006). These functions of the histone methyltransferase-containing complexes appear to play an important role in postimplantation gene repression by DNA methylation and represent a basic example of the cross talk between DNA methylation and histone posttranslational modifications.

\section{DNA methylation and endocrine diseases}

Epigenetic changes are not only responsible for normal development, but they are also involved in disease. Genetic lesions, including mutations, deletions, or breakages, are well known to produce disorders in humans, but there is increasing evidence that diseases can also be caused by epigenetic alterations. Changes in DNA methylation can cause silencing of normally active genes or activation of normally silent genes. This could occur in cancer, in hereditary disorders resulting from DNA methylation defects, and in late-onset diseases caused by the interaction of genomic, epigenetic, and environmental changes (Robertson 2005, Feinberg 2007).

The Beckwith-Wiedemann syndrome, an overgrowth disorder characterized by an increased risk of cancer and different malformations, is an example of a singlegene epigenetic disease. Some patients with BeckwithWiedemann syndrome show loss of imprinting of insulin-like growth factor 2 (IGF2), leading to an increase in the levels of this growth factor (DeBaun et al. 2002). A human disorder with multiple hormone resistance, the pseudohypoparathyroidism type IA (PHPIA), is also caused by tissue-specific differential imprinting of splice variants of the guanine nucleotide regulatory protein (encoded by GNAS1; Lalande 2001). Other class of monogenic diseases involves mutation of genes involved themselves in methylation machinery. For instance, Rett syndrome is caused by mutations that affect the methyl-CpG-binding protein MeCP2. Rett syndrome is a neurodevelopmental disorder that affects mainly females. Among other symptoms, affected patients can have seizures, present intellectual disability with learning difficulties, and have no verbal skills. This phenotype argues for the primacy of MeCP2, as opposed to other MBDs, in the silencing mechanism associated with DNA methylation, at least in the central nervous system. In Rett syndrome, DNA methylation is not altered, but gene silencing is abnormal because DNA methylation goes unrecognized (Bienvenu \& Chelly 2006).

Gene hypomethylation is a common event in cancer, although site-specific hypermethylation and other epigenetic chromatin modifications are also found in tumors (Cedar \& Bergman 2009). A large number of cancer-related genes that are silenced or activated by aberrantly methylated CpG islands have been identified in different types of tumors indicating that epigenetic events play a key role in tumorigenesis (Costello et al. 2000). Many growth-promoting genes are activated in tumors due to DNA hypomethylation and, not surprisingly, some major hypermethylated genes in cancer include tumor suppressors (Feinberg \& Vogelstein 1983). In the case of an imprinted tumor suppressor 
gene, hypermethylation of only one allele is sufficient to cause a total loss of its tumor suppressor function because the other allele is already inactive (Feinberg et al. 2006). On the contrary, loss of imprinting of an oncogene can lead to overexpression of the oncogenic protein and consequently to increased risk of tumor formation. Importantly, lymphocytes in $\sim 10 \%$ of the human population have loss of imprinting at the IGF2 locus. Interestingly, the IGF2 receptor (IGFR2) gene that functions as a tumor suppressor is not imprinted in humans but is imprinted and has a maternal expression in mice. Therefore, it has been predicted that the incidence of tumors resulting from IGFR2 inactivation should be lower in humans than in mice (Jirtle \& Skinner 2007).

DNA methylation of tumor suppressor genes is common in endocrine cancer. To give a few examples, epigenetic gene silencing of tumor suppressor genes, including E-cadherin, PTEN, RASSF1A, and FGFR2, and of differentiation-related genes, such as TSH receptor and the sodium-iodide symporter, has been reported in thyroid cancers (Kondo et al. 2006, 2007, Xing 2007). Frequent promoter hypermethylation of the APC, RASSF1A, or Rap1GAP tumor suppressors is found in parathyroid tumors (Juhlin et al. 2010). von Hippel-Lindau inactivation by promoter methylation is an important pathway for the development of malignant sporadic pancreatic endocrine tumors (Schmitt et al. 2009) and pheochromocytomas (Cascon et al. 2004), and loss of pRb and neuronatin expression is associated with promoter hypermethylation in pituitary adenomas (Simpson et al. 2000, Dudley et al. 2009, Revill et al. 2009).

The existence of hormone-independent tumors is a substantial problem for the treatment of several endocrine tumors with hormone antagonists. Hypermethylation can selectively silence multiple promoters of steroid receptors in hormone-dependent cancers, including ovarian, endometrial, breast, and prostate cancer. Aberrant DNA methylation of the promoter region of estrogen (ER), progesterone (PR), and androgen (AR) receptors can play an important role in the loss of hormone dependence, although resistance to hormonal treatment can appear even in the presence of steroid receptor expression (Lapidus $e t$ al. 1996, Jarrard et al. 1998, Sasaki et al. 2003, Asada et al. 2008). Interestingly, DNMT inhibitors such as 5-aza-2'deoxycytidine and HDAC inhibitors such as trichostatin A have been successfully used to induce ER expression in ER-negative breast cancer cells (Ferguson et al. 1995) and to sensitize hormone-resistant ER-negative breast cancer cells to tamoxifen (Jang et al. 2004). It is increasingly recognized that epigenetic gene silencing plays a major role in tumor initiation and progression in hormone-dependent cancers. Indeed, in the first genome-wide DNA methylation profiling according to the receptor status of breast cancer, it has been found that ER/PR status affects the global DNA methylation profile (Li et al. 2010).

Expression of other non-steroid hormone nuclear receptors has also been found to be inactivated by promoter DNA methylation in tumors. This is the case for the thyroid hormone receptor $\beta$ isoform (TR $\beta$ ), which can function as a tumor suppressor (Martinez-Iglesias et al. 2009, Garcia-Silva et al. 2011). The TR $\beta$ promoter is methylated in early stage breast cancer tumors ( $\mathrm{Li}$ et al. 2002). The same occurs with the retinoic acid receptor $\beta$ (RAR $\beta$ ). Retinoic acid (RA), an active metabolite of vitamin A, plays a key role in development and has important antitransforming actions in many types of cancer cells. RAR $\beta$ is one of the tumor suppressor genes that are more often epigenetically inactivated in tumors (Esteller et al. 2002). Very recently, it has been found that RA plays a key role in the fate of intestinal cells through regulation of DNA demethylase activity (Rai et al. 2010). DNA demethylation has been proposed to involve the cooperative actions of proteins from the cytidine deaminase family (activation-induced deaminase and Apobec2), the G:T mismatch-specific glycosylase family (MBD4), and a DNA repair protein family (GADD45; Rai et al. 2008). However, the role of GADD45 in promoting DNA demethylation is still controversial (Jin et al. 2008) and DNA methylation is conserved in genetically modified mice lacking GADD45 (Engel $e t$ al. 2009). Loss of the adenomatous polyposis coli (APC) tumor suppressor gene is the key initiating step in a model of genetic and epigenetic events that lead to colorectal cancer. Loss of APC causes upregulation of a DNA demethylase system and the concomitant hypomethylation of key intestinal cell fating genes, whereas RA strongly downregulates demethylase components, thereby promoting DNA methylation of key genes and helping progenitor cells commit to differentiation (Rai et al. 2010).

\section{Hormonal control of DNA methylation/ demethylation at target promoters}

Although the mechanisms of DNA demethylation are not yet totally understood and remain a controversial issue (Ooi \& Bestor 2008), recent data obtained studying the effect of hormones, mainly ligands of nuclear receptors, on transcription of their target genes indicate that they can mediate active DNA demethylation occurring independently of DNA replication. One of the first evidence was obtained with the glucocorticoid receptor (GR). Glucocorticoids cause local DNA demethylation of the tyrosine aminotransferase (Tat) gene around a glucocorticoid response element that is located $2.5 \mathrm{~kb}$ upstream of the 
transcriptional start site. Kress et al. (2006), showed that demethylation is a consequence of an active mechanism that involves the creation of DNA nicks $3^{\prime}$ to the methylcytidine and the participation of a demethylase initiating a base excision repair.

GR-dependent demethylation was slow since it was detected after a few hours of stimulation. However, a rapid methylation/demethylation at the ER target gene pS2 has been observed in breast cancer cells (Kangaspeska et al. 2008, Metivier et al. 2008). It had been previously shown that ER is recruited in a cyclic manner to the pS2 promoter and that this is followed by the assembly of coactivators, which in turn provokes local structural changes in chromatin. This allows the engagement of the basal transcription machinery and the activation of the RNA polymerase II, which is then followed by the recruitment of corepressor complexes and the initiation of the next transcriptional cycle (Metivier et al. 2003). Remarkably, these changes are accompanied by changes in the methylation of $\mathrm{CpG}$ dinucleotides in the pS2 promoter and breaks in the sugar-phosphate backbone of DNA. Cyclical methylation and demethylation of $\mathrm{CpG}$ dinucleotides had a periodicity of around $100 \mathrm{~min}$, implying the existence of an active demethylation process. Methylation takes place at each transcriptional cycle after the occupancy of ER and polymerase II and is connected with the recruitment of MeCP2 and DNMT1 to the pS2 promoter. Recruitment of MBD2 and MBD3 occurs later, simultaneously with the recruitment of the remodeling complex NuRD. CpG methylation at the pS2 promoter is strand specific, occurring primarily in the transcribed strand. DNMTs appear to exhibit dual actions during these cycles, being involved in CpG methylation and also in active demethylation of 5mCpGs through deamination. As stated above, demethylation of the Tat gene involves the formation of DNA nicks, and CpG methylation/demethylation at the pS2 promoter also involves a base excision repair process with base substitution (Metivier et al. 2008). The following process has been suggested: deamination of $5 \mathrm{mC}$ by DNMT3A or DNMT3B would result in a T/G mismatch, which would be repaired by a thymine DNA glycosylase by excision of the mispaired cytosine, generating an abasic residue. This would be followed by the action of apurinic/apyrimidinic endonuclease I, which would create a single nucleotide gap by cleaving the phosphodiester bond $5^{\prime}$ to the excised base. Then, DNA polymerase $\beta$ would replace the missing nucleotide and finally a DNA ligase would end the repairing process (Reid et al. 2009; Fig. 3).

Another example of rapid methylation/demethylation in a hormonally regulated promoter has been provided by the cytochrome p450 27B1 (CYP27B1), the final enzyme in vitamin D biosynthesis (Kim et al. 2009). CYP27B1 gene expression is regulated by two calcemic

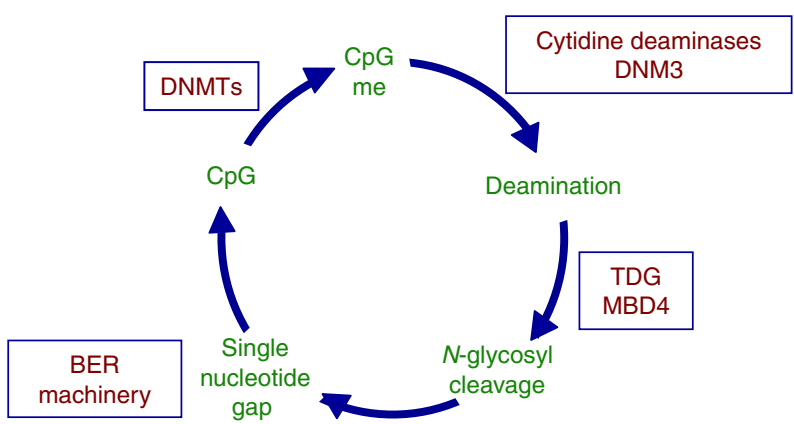

Figure 3 Proposed model for active DNA methylation/demethylation at steroid hormone target promoters. The process would involve deamination to thymidine resulting in T/G mismatch. The action of a thymine DNA glycosylase (TDG) such as MBD4 would initiate a process of repair that would be completed by the base excision repair (BER) machinery leading to unmethylated $\mathrm{CpG}$, which can then be again methylated by DNMTs starting a new cycle.

hormones: parathyroid hormone (PTH) and vitamin D. PTH activates CYP27B1 transcription through stimulation of protein kinases A and C (PKA and PKC), whereas vitamin $\mathrm{D}$ through binding to its nuclear receptor, VDR, represses CYP27B1 transcription. A basic helix-loop-helix transcriptional activator (VDRinteracting repressor, VDIR) binds to the CYP27B1 promoter and VDR interacts with VDIR and represses transcription by means of recruiting a HDAC corepressor complex (Murayama et al. 2004). Reflecting vitaminD-mediated transrepression of the CYP27B1 gene, rapid methylation of CpG sites is induced by vitamin $\mathrm{D}$ in this gene promoter. This methylation step requires DNMT1 and DNMT3B. Conversely, treatment with PTH causes active CpG demethylation of the CYP27B1 promoter. Purification of a VDIR-associated complex showed the presence of both DNMTs and the DNA glycosylase MBD4 in the complex. Activation of PKC by PTH causes MBD4 phosphorylation and activation. The DNA glycosylase would cause the excision of the mispaired nucleotide and a base excision repair process would achieve $\mathrm{CpG}$ demethylation of the promoter (Kim et al. 2009). Thus, the results obtained with the CYP27B1 promoter further suggest that DNA methylation/demethylation plays an important role in hormonal regulation of transcription.

Other member of the CYP superfamily, oxysterol $7 \alpha$-hydroxylase (CYP7B1), is also regulated by DNA methylation. The nuclear receptor peroxisome proliferator-activated receptor $\alpha(\operatorname{PPAR} \alpha)$ represses liver expression of CYP7B1 in females but not in males. This inhibition appears to involve a sex-specific sumoylation of the receptor and is mediated by methylation of a Sp1 site in the CYP7B1 promoter, which contains a $\mathrm{CpG}$ dinucleotide. Methylation of this CpG inhibits binding of Sp1 to the promoter. Furthermore, complexes containing MBDs, NCoR, 
HDACs, and histone methyltransferases are recruited to methylated DNA (Yoon et al. 2003), and it was found that these complexes are involved in inhibition of CYP7B1 gene transcription by PPAR $\alpha$ (Leuenberger et al. 2009).

\section{DNA methylation and the persistent neonatal effects of glucocorticoids in the brain}

Exposure to stress during neurodevelopment has an effect on the quality of physical and mental health. Maternal care might influence hypothalamic-pituitaryadrenal (HPA) function in the rat through epigenetic programming of GR expression (Weaver et al. 2007). In humans, childhood abuse alters HPA stress responses and increases the risk of suicide. Decreased levels of $G R$ mRNA and increased methylation of the GR promoter were found in hippocampus from abused suicide victims that also showed a decrease in NGFI-A transcription factor binding. These findings translate previous results from rat to humans and suggest a common effect of parental care on the epigenetic regulation of hippocampal GR expression (McGowan et al. 2009). The most normally used technique to induce early life stress is periodic infant-mother separation during the neonatal period. This causes an irreversible increase in glucocorticoid secretion with disruption of the activity of the HPA axis and increased sensitivity to stress later in life, which are related to disorders of mood and cognition. Murgatroyd et al. (2009) have examined the expression of AVP and CRH in early life stress. These hypothalamic secretagogues regulate HPA axis activity by increasing ACTH expression. They found that neonatal stress induces lifelong hypomethylation of the $A V P$ gene, causing increased AVP expression, activation of the HPA axis, and behavioral alterations. They found that hypomethylated $\mathrm{CpG}$ residues serve as DNA-binding sites for MeCP2 that is phosphorylated by CaMKII after depolarization of hypothalamic cells. Thus, this study defines this methyl CpG-binding protein as an important component in the epigenetic programming of neuroendocrine and behavioral functions.

There is evidence for hypercortisolemia playing a role in the generation of psychiatric symptoms and for epigenetic variation within HPA axis genes mediating behavioral changes also in the adult. When mice are treated with corticosterone, they exhibit anxiety-like behavior together with a significant decrease in the hippocampal mRNA levels of GR and an increase in the stress-related gene $F k b p 5$. This gene encodes a co-chaperone of hsp90 that binds to GR and promotes cytoplasmic localization of the receptor, regulating GR sensitivity. Differences were seen in Fkbp5 methylation in hippocampus and hypothalamus of glucocorticoidtreated animals. The same occurs in a mouse hippocampal neuronal cell line exposed to corticosterone. This suggests that DNA methylation plays a role in mediating effects of glucocorticoid exposure on FKBP5 function, with potential consequences for behavior (Lee et al. 2010).

Lower weight at birth is associated not only with risk of metabolic syndrome but also with cardiovascular disease and hypertension in adulthood (Stein et al. 1996, Heijmans et al. 2008). The renin-angiotensin system appears to play a role in this process since a maternal low-protein diet results in undermethylation of the At1b angiotensin receptor promoter and early overexpression of this gene in the adrenal of offspring (Bogdarina et al. 2007). Furthermore, maternal glucocorticoids modulate this effect on fetal DNA methylation since treatment of rat dams with the $11-\beta$-hydroxylase inhibitor metyrapone prevents the epigenetic change and hypertension in the offspring (Bogdarina et al. 2010). Collectively, these studies suggest that DNA methylation might have an important role on the long-term effects of glucocorticoids in neonatal brains. However, as the absolute changes are low and the cell-type composition was not always systematically analyzed, further studies are needed to determine the functional role of epigenetic factors in the long-term effects of early development.

The pro-opiomelanocortin $(P O M C)$ gene plays an important role not only in the regulation of the HPA axis and adrenal development but also in obesity. The POMC gene is activated in ACTH-dependent Cushing's syndrome. This disorder may be a consequence of activation of the highly tissue-specific POMC promoter in pituitary and non-pituitary sites. This promoter contains a CpG island, which is methylated in normal non-expressing tissues, but is specifically demethylated in expressing tissues and tumors (Newell-Price et al. 2001). Methylation near the response element for the tissue-specific POMC activator PTX1 abolishes binding of this transcription factor that plays a key role in pituitary development. It has been suggested that the POMC promoter could show different degree of methylation in POMC-expressing hypothalamic neurons, thus influencing food intake and obesity (Newell-Price 2003).

\section{DNA methylation and gonadal hormones in the developing brain}

Many brain sex-specific features arise from effects of the gonadal steroid hormones, which are exerted during the perinatal period. Testosterone is converted into estradiol within developing neurons, and estradiol mediates several developmental sex differences in cell 
anatomy and physiology. These differences are responsible for dimorphic regulation of pituitary gonadotropin secretion and for sex-specific behavior (McCarthy 2008). Alterations in DNA methylation of genes essential for sexual brain differentiation, including $\mathrm{ER} \alpha, \mathrm{ER} \beta$, and the PR themselves, have been described to be sex and hormonally regulated. Methylation of the ER $\alpha$ promoter within the preoptic area, which is crucial for sexual behavior, is influenced by maternal care during the neonatal period in rodents. Thus, maternal licking and grooming has been demonstrated to alter ER $\alpha$ promoter methylation, and consequently ER $\alpha$ expression, in a sex-specific manner (Champagne et al. 2006). In addition, methylation of the ER $\alpha$ gene in the preoptic area is higher in newborn females than in males or estradiol-treated females, and sex and hormone-mediated differences in methylation were also observed at later stages (Kurian et al. 2010). While $\mathrm{ER} \alpha$ activation is required for neonatal brain masculinization, ER $\beta$ activation appears to be involved in brain defeminization and in the regulation of neuroendocrine functions, since this receptor colocalizes with neuroendocrine hormones such as GnRH, $\mathrm{CRH}$, oxytocin, vasopressin, or prolactin. CpG methylation of the $E R \beta$ gene in the preoptic area, hypothalamus, or hippocampus of newborns is not significantly influenced by sex or hormonal treatment. However, there are differences in ER $\beta$ methylation in these brain areas in the adult (Schwarz et al. 2010). On the other hand, whereas in hypothalamus of newborn animals no sex differences in PR promoter methylation are detected, significantly lower levels are found in adolescent females than males. It has been suggested that gonadal female hormones promote PR methylation in the hypothalamus, silencing PR expression during the critical period of sexual differentiation in the male, a process that is essential for masculine behavior in the adult.

Whereas DNA methylation can be profoundly influenced by gonadal hormones during brain development, the effect of these hormones in the adult brain has received less attention. However, it has been recently reported that testosterone regulates expression of vasopressin (AVP) within the bed nucleus of the stria terminalis (BST) in the adult brain. Castration of male rats strongly inhibits AVP expression in this nucleus, and this inhibition is reversed on testosterone treatment. It was found that castration results in AVP promoter methylation at specific CpG sites in the BST. Conversely, castration significantly increased ER $\alpha$ mRNA levels by decreasing ER $\alpha$ promoter methylation. These results suggest that the DNA methylation pattern of some steroid responsive genes is actively regulated by gonadal steroid hormones in the adult brain. It is intriguing the opposite regulation of ER $\alpha$ and AVP promoter methylation in response to changes in steroid hormone levels in the same brain region, and how this specificity is regulated remains to be elucidated. In any case, these results indicate that regulation of DNA methylation in the adult brain could play a role in the hormonal control of behavior (Auger et al. 2011).

\section{Endocrine disruptors and their possible transgenerational effects}

Epigenetic factors can be altered by the environment (Fraga et al. 2005, Baryshnikova et al. 2008, Stidley et al. 2010), and increasing evidence suggests that a large variety of environmental and dietary chemicals can interfere with normal endocrine functions and result in adverse consequences. Initial animal studies demonstrated that compounds with estrogenic activity can disrupt reproductive tract function. However, it is now evident that different chemical compounds, referred to as 'endocrine disruptors', can either mimic or interfere with the normal actions of hormones including not only sexual steroids, but also thyroid, hypothalamic, and pituitary hormones (Newbold et al. 2006). The effect of endocrine disruptors is particularly strong when exposure occurs during fetal or neonatal periods. If exposure occurs during these critical stages, it can produce permanent effects that may be observed much later in life. For instance, exposure of newborn mice to environmental estrogens causes uterine lesions and uterine tumors in adults. Mechanistic studies provided support that estrogens cause both genetic and epigenetic alterations in developing target tissues. Thus, the estrogen-responsive genes lactoferrin and c-fos are permanently upregulated in the uterus after developmental exposure to the estrogen-like compound diethylstilbestrol (DES) due to hypomethylation of the promoter region of these genes after exposure to this chemical ( $\mathrm{Li}$ et al. 1997, 2003). DES was prescribed during many years to pregnant women to prevent spontaneous abortions. More recently, Tang et al. (2008) identified 14 genes whose methylation patterns are altered after neonatal treatment with DES or genistein (other estrogenic compound), among them the gene encoding the nucleosomal binding protein 1 (NSBP1), a nucleosome core particle binding protein that plays a role in chromatin remodeling. On the other hand, bisphenol-A is a non-steroidal estrogen that is ubiquitous in the environment. Bromer et al. (2010) have recently demonstrated that methylation of the Hoxa10 gene was decreased in the reproductive tract of mice exposed in utero to bisphenol-A. Decreased DNA methylation led to an increase in binding of ER $\alpha$ to the Hoxa10 promoter and to increased estrogen-dependent transcription. Permanent epigenetic alteration of sensitivity to estrogen may then be a mechanism through which endocrine disruptors exert their action. 
The demonstration that many estrogenic compounds show lifelong effects in animals has raised the concern that fetal and neonatal exposure to these compounds in humans could also produce epigenetic changes and impact negatively human health. For instance, human fetuses can be exposed to high estrogen levels, due to unintentional continuation of birth control pill intake by the mother before detection of pregnancy. On the other hand, exposure of the mother to environmental estrogen disruptors or intake of high levels of phytoestrogens can affect the fetus and even the infant during breastfeeding, with possible adverse consequences (Prins 2008).

Although epigenetic transgenerational inheritance is a controversial issue at the moment, results obtained with experimental animals have suggested that adverse effects caused by endocrine disruptors may be transmitted to subsequent generations. Environmental factors may induce epigenetic changes in the germ line, which would be passed to the progeny (Jirtle \& Skinner 2007). In agreement with this hypothesis, the susceptibility for tumors after treatment with DES was transmitted to the descendants through the maternal germ cell lineage (Newbold et al. 1998), and prenatal exposure to the endocrine disruptors vinclozolin (an antiandrogenic compound) or methoxychlor (an estrogenic compound) induced an adult phenotype in the $F_{1}$ generation of decreased spermatogenic capacity and increased incidence of male infertility. Furthermore, these effects were described to be transferred through the male germ line to nearly all males of several generations (Anway et al. 2005). However, the transgenerational effects have not been reproduced by other groups (Renner 2009), casting some doubts on the transmission of the effects of vinclozolin beyond the $\mathrm{F}_{1}$ generation. In contrast, a recent study has examined genome-wide promoter DNA methylation alterations in the sperm of $F_{3}$ generation rats whose $\mathrm{F}_{0}$ generation mother was exposed to vinclozolin (Guerrero-Bosagna et al. 2010). This study has identified 52 different regions with altered methylation in the sperm promoter epigenome, suggesting again that an endocrine disruptor could have the ability to induce epigenetic transgenerational changes. As the DNA methylation differences reported in this study are very marginal, further investigations are needed to fully characterize the putative heritability of epigenetic factors.

\section{Type 2 diabetes, metabolism, and DNA methylation}

Insulin plays a key role in metabolic control, and therefore, regulation of insulin gene expression has been extensively analyzed. However, only recently it has been shown that the insulin promoter is demethylated specifically in pancreatic $\beta$ cells both in humans and in mice. The insulin gene is methylated in mouse embryonic stem cells and becomes demethylated on differentiation into insulin-expressing cells. Methylation of a specific CpG located in a cAMP response element (CRE) of the insulin promoter inhibits association of the transcription factors CREB and ATF2 that bind to the CRE, while inducing MeCP2 recruitment, leading to a strong reduction of promoter activity (Kuroda et al. 2009). Therefore, promoter demethylation may play an important role in the specific expression of the insulin gene in pancreatic $\beta$ cells.

Abnormal nutrition during embryonic development has been shown to influence disease susceptibility in the descendants. The global prevalence of obesity and type 2 diabetes is increasing, and parent obesity is a risk factor for developing obesity in childhood (Whitaker et al. 1997). In rodents, it has been shown that when mothers are fed with a high-fat diet (HFD), male offspring exhibit increased body weight and are diabetic and insulin resistant. Furthermore, the offspring of these males also present insulin resistance, showing that fathers can start intergenerational inheritance of metabolic diseases (Dunn \& Bale 2009). Accordingly, paternal HFD alters gene expression in pancreatic $\beta$ cells of adult female offspring. The Il13ra2 gene, a gene belonging to the Jak-Stat signaling pathway, presented the highest difference in gene expression. An epigenetic mechanism appears to contribute to the altered Il13ra2 expression, since methylation at CpG -960 of Il13ra2 was significantly reduced in HFD offspring with respect to controls. This CpG is located in a putative recognition site for the transcription factor TCF-1A and for the methylated DNA binding protein NF-X. These results show that paternal HFD could affect metabolism of the offspring by epigenetic regulation of genes important for pancreatic $\beta$ cell function ( $\mathrm{Ng}$ et al. 2010).

Offspring of males fed a low-protein diet also exhibit metabolic disturbances. Epigenomic profiling of offspring livers reveals changes in cytosine methylation depending on paternal diet, including reproducible changes in DNA methylation of PPAR $\alpha$, a key lipid regulator. These results indicate that parental diet can affect cholesterol and lipid metabolism in offspring and define a model system to study environmental reprogramming of the heritable epigenome (Carone et al. 2010).

Intrauterine growth restriction (IUGR) also increases susceptibility to age-related diseases, including type 2 diabetes. In a rodent model of IUGR, which develops diabetes in adulthood, global decreases in DNA methylation concomitant with a decrease in DNMT1, MeCP2, and HDAC1 is observed in tissues such as liver 
or brain (Lillycrop 2011). Furthermore, it was found that expression of PDX1, a pancreatic and duodenal homeobox 1 transcription factor critical for $\beta$ cell function and development, was permanently reduced in IUGR $\beta$ cells and underwent epigenetic modifications: throughout development, there were epigenetic histone modifications, but after the onset of diabetes in adulthood, the CpG island in the proximal $P d x 1$ promoter was methylated, resulting in permanent silencing of the Pdx1 locus (Park et al. 2008). Thompson et al. (2010) have generated the first DNA methylation map at almost 1 million unique sites throughout the rat genome in normal pancreatic islet cells, allowing the identification of the changes that

Table 1 Examples of endocrine conditions associated with DNA methylation changes

\section{Endocrine condition}

Beckwith-Wiedemann

PHPIA

Endocrine cancers

Type 2 diabetes

Neuroendocrine disorders of mood and cognition

Cardiovascular disease and hypertension in adulthood

Cushing's syndrome

Sexual hormones and the brain

Endocrine disruptors
Alteration

Loss of imprinting of IGF2

Differential imprinting of GNAS1

Methylation of tumor suppressor genes

Aberrant promoter methylation of $\mathrm{ER} \alpha, \mathrm{PR}, \mathrm{AR}, \mathrm{TR} \beta$, and RAR $\beta$

Regulation of DNA demethylase activity in intestinal cancer

Paternal high-fat diet decreases $/ / 13 \mathrm{ra} 2$ promoter methylation in pancreatic $\beta$ cells of the offspring

Paternal low-protein diet alters PPAR $\alpha$ methylation in livers of the offspring

Intrauterine growth restriction decreases globally DNA methylation as well as DNMT1 and MeCP2 expression

Permanent methylation of the $P d x 1$ gene in $\beta$ cells after intrauterine growth restriction

Intrauterine growth restriction causes changes in DNA

methylation in the proximity of genes with important roles in $\beta$ cell function and development

HNF $4 \alpha$ methylation in offspring of malnourished mothers

PPAR $\gamma \mathrm{C} 1 \alpha$ methylation after overfeeding

Maternal care affects brain GR methylation in rodents

GR methylation in childhood abuse victims

AVP hypomethylation and upregulation of HPA axis after infant-mother separation

Glucocorticoids decrease GR expression and reduces methylation of the anxiety-related gene Fkbp5

Maternal low-protein diet induces undermethylation of At1b angiotensin receptor promoter in the adrenal of the offspring

Glucocorticoid administration prevents At $1 \mathrm{~b}$ methylation and hypertension in the offspring

Demethylation of the POMC promoter in non-pituitary cells and tumors

Maternal care alters $\mathrm{ER} \alpha$ promoter methylation in the preoptic area of the brain and sexual behavior

Higher ER $\alpha$ methylation in the preoptic area of females

Sexual differences in ER $\beta$ methylation in various brain areas

Castration of male rats causes methylation of the AVP promoter and reduces $\mathrm{ER} \alpha$ methylation in the bed nuclei of the stria terminalis

Increased methylation of the memory suppressor gene reelin by estradiol

Hypomethylation of estrogen-responsive genes in the uterus after treatment with DES

Changes in NSBP1 promoter methylation after neonatal treatment with DES or genistein

Undermethylation of the Hoxa10 gene in the reproductive tract of mice exposed in utero to bisphenol-A

Increased expression of DNMT3A and DNMT3L in testis and prostate of rats exposed to vinclozolin during gonadal sex determination

Altered methylation pattern in 52 regions of the sperm in descendants of rats exposed to vinclozolin

\section{References}

DeBaun et al. (2002)

Lalande (2001)

Cascon et al. (2004), Kondo et al. (2006, 2007), Xing (2007) and Juhlin et al. (2010)

Esteller et al. (2002), Li et al. (2002) and Asada et al. (2008)

Rai et al. (2010)

$\mathrm{Ng}$ et al. (2010)

Carone et al. (2010)

Lillycrop (2011)

Park et al. (2008)

Thompson et al. (2010)

Sandovici et al. (2011)

Brons et al. (2010)

Weaver et al. (2007)

McGowan et al. (2009)

Murgatroyd et al. (2009)

Lee et al. (2010)

Bogdarina et al. (2007)

Bogdarina et al. (2010)

Newell-Price (2003)

Champagne et al. (2006)

Kurian et al. (2010)

Schwarz et al. (2010)

Auger et al. (2011)

Zhao et al. (2010)

Lee et al. (2003)

Tang et al. (2008)

Bromer et al. (2010)

Anway et al. (2008) and Cowin et al. (2010)

Guerrero-Bosagna et al. (2010) 
occur as a consequence of IUGR. Comparison of growth restricted with normal rats revealed changes in DNA methylation at a number of novel loci, not limited to canonical CpG islands or promoters. The specific loci affected are in proximity to genes with important roles in $\beta$ cell function and development, suggesting that that epigenetic dysregulation is a strong candidate for propagating the cellular memory of intrauterine events, causing changes in expression of nearby genes and long-term susceptibility to type 2 diabetes.

Low birth weight and unhealthy diets are also risk factors for metabolic disease including type 2 diabetes. Genetic, non-genetic, and epigenetic data propose a role of the key metabolic regulator PPAR $\gamma$ coactivator $1 \alpha(\mathrm{PPAR} \gamma \mathrm{C} 1 \alpha)$ in the development of type 2 diabetes. When challenged with high-fat overfeeding, low birth weight subjects develop insulin resistance and reduced PPAR $\gamma \mathrm{C} 1 \alpha$ and OXPHOS gene expression. PPAR $\gamma \mathrm{Cl} \alpha$ methylation was significantly higher in low birth weight subjects during the control diet. However, PPAR $\gamma \mathrm{Cl} \alpha$ methylation increased in only normal birth weight subjects after overfeeding. These changes are reversible, supporting that DNA methylation induced by overfeeding is reversible in humans (Brons et al. 2010). Moreover, in a very recent study, it has been shown that the increased risk of type 2 diabetes in the offspring of malnourished mothers was associated with the decreased expression of the orphan nuclear receptor HNF $4 \alpha$, previously linked with this type of diabetes. Specifically, a pancreas-specific enhancer of HNF $4 \alpha$ expression is epigenetically inactivated by DNA methylation in the adult offspring of poorly nourished mothers, revealing a novel mechanism by which maternal diet and aging interact through epigenetic processes to determine the risk of age-associated endocrine diseases (Sandovici et al. 2011).

\section{Conclusions and perspectives}

Epigenetic mechanisms may play a key role in normal endocrine physiology, as well as in the development of endocrine diseases. A summary of the changes in DNA methylation observed to date in relation to different endocrine conditions is illustrated in Table 1. A better knowledge of the association between epigenetic mechanisms and endocrine function should lead to a better understanding of the molecular basis of endocrine disorders and could help to the development of novel therapeutic strategies. DNA methylation acts at many levels to regulate hormonal actions: during development, in response to environmental factors and endocrine disruptors, in endocrine cancer, endocrine therapies, etc. Although many aspects of endocrine system epigenetics are still unknown, the recent advances described here shed a new light on the importance of this epigenetic modification in the functioning of the endocrine glands and on the response of target tissues to hormones. The recent development of ultra-high-throughput technologies will allow the description of the whole genome DNA modifications that occur in endocrine physiology and pathology. These data hold the potential of defining the epigenetic signatures associated with endocrine disorders for future use as diagnostic markers and can lead to the development of novel epigenetic drugs with therapeutic applications in specific endocrinological diseases.

\section{Declaration of interest}

The authors declare that there is no conflict of interest that could be perceived as prejudicing the impartiality of this review.

\section{Funding}

The laboratory of A A is supported by Grants BFU2007-62402 from Ministerio de Ciencia e Innovación, RD06/0020/0036 from the Fondo de Investigaciones Sanitarias and by the European Grant CRESCENDO (FP-018652). The Cancer Epigenetics Unit at the IUOPA is supported by grants from the Spanish Ministry of Health (PS09/02454) and the Community of Asturias (FICYT IB09-106). The IUOPA is supported by the Obra Social Cajastur, Spain.

\section{References}

Aapola U, Liiv I \& Peterson P 2002 Imprinting regulator DNMT3L is a transcriptional repressor associated with histone deacetylase activity. Nucleic Acids Research 30 3602-3608. (doi:10.1093/nar/ gkf474)

Aguilera O, Fernandez AF, Munoz A \& Fraga MF 2010 Epigenetics and environment: a complex relationship. Journal of Applied Physiology 109 243-251. (doi:10.1152/japplphysiol.00068.2010)

Anway MD \& Skinner MK 2008 Transgenerational effects of the endocrine disruptor vinclozolin on the prostate transcriptome and adult onset disease. Prostate 68 517-529. (doi:10.1002/pros.20724)

Anway MD, Cupp AS, Uzumcu M \& Skinner MK 2005 Epigenetic transgenerational actions of endocrine disruptors and male fertility. Science 308 1466-1469. (doi:10.1126/science.1108190)

Anway MD, Rekow SS \& Skinner MK 2008 Transgenerational epigenetic programming of the embryonic testis transcriptome. Genomics 91 30-40. (doi:10.1016/j.ygeno.2007.10.002)

Aranda A \& Pascual A 2001 Nuclear hormone receptors and gene expression. Physiological Reviews 81 1269-1304.

Asada H, Yamagata Y, Taketani T, Matsuoka A, Tamura H, Hattori N, Ohgane J, Shiota K \& Sugino N 2008 Potential link between estrogen receptor-alpha gene hypomethylation and uterine fibroid formation. Molecular Human Reproduction 14 539-545. (doi:10.1093/ molehr/gan045)

Auger CJ, Coss D, Auger AP \& Forbes-Lorman RM 2011 Epigenetic control of vasopressin expression is maintained by steroid hormones in the adult male rat brain. PNAS $1084242-4247$. (doi:10.1073/pnas.1100314108)

Baryshnikova E, Destro A, Infante MV, Cavuto S, Cariboni U, Alloisio M, Ceresoli GL, Lutman R, Brambilla G, Chiesa G et al. 2008 
Molecular alterations in spontaneous sputum of cancer-free heavy smokers: results from a large screening program. Clinical Cancer Research 14 1913-1919. (doi:10.1158/1078-0432.CCR-07-1741)

Beck S 2010 Taking the measure of the methylome. Nature Biotechnology 28 1026-1028. (doi:10.1038/nbt1010-1026)

Bienvenu T \& Chelly J 2006 Molecular genetics of Rett syndrome: when DNA methylation goes unrecognized. Nature Reviews. Genetics 7 415-426. (doi:10.1038/nrg1878)

Bird AP \& Wolffe AP 1999 Methylation-induced repression - belts, braces, and chromatin. Cell 99 451-454. (doi:10.1016/S00928674(00)81532-9)

Bogdarina I, Welham S, King PJ, Burns SP \& Clark AJ 2007 Epigenetic modification of the renin-angiotensin system in the fetal programming of hypertension. Circulation Research 100 520-526. (doi:10.1161/01.RES.0000258855.60637.58)

Bogdarina I, Haase A, Langley-Evans S \& Clark AJ 2010 Glucocorticoid effects on the programming of ATlb angiotensin receptor gene methylation and expression in the rat. PLoS ONE 5 e9237. (doi:10. 1371/journal.pone.0009237)

Bromer JG, Zhou Y, Taylor MB, Doherty L \& Taylor HS 2010 BisphenolA exposure in utero leads to epigenetic alterations in the developmental programming of uterine estrogen response. FASEB Journal 24 2273-2280. (doi:10.1096/fj.09-140533)

Brons C, Jacobsen S, Nilsson E, Ronn T, Jensen CB, Storgaard H, Poulsen P, Groop L, Ling C, Astrup A et al. 2010 Deoxyribonucleic acid methylation and gene expression of PPARGC1A in human muscle is influenced by high-fat overfeeding in a birth-weightdependent manner. Journal of Clinical Endocrinology and Metabolism 95 3048-3056. (doi:10.1210/jc.2009-2413)

Carone BR, Fauquier L, Habib N, Shea JM, Hart CE, Li R, Bock C, Li C, Gu H, Zamore PD et al. 2010 Paternally induced transgenerational environmental reprogramming of metabolic gene expression in mammals. Cell 143 1084-1096. (doi:10.1016/j.cell.2010.12.008)

Cascon A, Ruiz-Llorente S, Fraga MF, Leton R, Telleria D, Sastre J, Diez JJ, Martinez Diaz-Guerra G, Diaz Perez JA, Benitez J et al. 2004 Genetic and epigenetic profile of sporadic pheochromocytomas. Journal of Medical Genetics 41 e3. (doi:10.1136/jmg.2003.012658)

Cedar H \& Bergman Y 2009 Linking DNA methylation and histone modification: patterns and paradigms. Nature Reviews. Genetics 10 295-304. (doi:10.1038/nrg2540)

Champagne FA, Weaver IC, Diorio J, Dymov S, Szyf M \& Meaney MJ 2006 Maternal care associated with methylation of the estrogen receptor-alphalb promoter and estrogen receptor-alpha expression in the medial preoptic area of female offspring. Endocrinology 147 2909-2915. (doi:10.1210/en.2005-1119)

Chen T \& Li E 2006 Establishment and maintenance of DNA methylation patterns in mammals. Current Topics in Microbiology and Immunology 301 179-201. (doi:10.1007/3-540-31390-7_6)

Costello JF, Fruhwald MC, Smiraglia DJ, Rush LJ, Robertson GP, Gao X, Wright FA, Feramisco JD, Peltomaki P, Lang JC et al. 2000 Aberrant CpG-island methylation has non-random and tumour-type-specific patterns. Nature Genetics 24 132-138. (doi:10.1038/72785)

Cowin PA, Gold E, Aleksova J, O’Bryan MK, Foster PM, Scott HS \& Risbridger GP 2010 Vinclozolin exposure in utero induces postpubertal prostatitis and reduces sperm production via a reversible hormone-regulated mechanism. Endocrinology 151 783-792. (doi:10.1210/en.2009-0982)

DeBaun MR, Niemitz EL, McNeil DE, Brandenburg SA, Lee MP \& Feinberg AP 2002 Epigenetic alterations of H19 and LIT1 distinguish patients with Beckwith-Wiedemann syndrome with cancer and birth defects. American Journal of Human Genetics 70 604-611. (doi:10.1086/338934)

Dudley KJ, Revill K, Clayton RN \& Farrell WE 2009 Pituitary tumours: all silent on the epigenetics front. Journal of Molecular Endocrinology 42 461-468. (doi:10.1677/JME-09-0009)

Dunn GA \& Bale TL 2009 Maternal high-fat diet promotes body length increases and insulin insensitivity in second-generation mice. Endocrinology 150 4999-5009. (doi:10.1210/en.2009-0500)
Engel N, Tront JS, Erinle T, Nguyen N, Latham KE, Sapienza C, Hoffman B \& Liebermann DA 2009 Conserved DNA methylation in Gadd45a (-/-) mice. Epigenetics 4 98-99. (doi:10.4161/epi.4.2. 7858)

Esteller M 2005 Aberrant DNA methylation as a cancer-inducing mechanism. Annual Review of Pharmacology and Toxicology $\mathbf{4 5}$ 629-656. (doi:10.1146/annurev.pharmtox.45.120403.095832)

Esteller M, Fraga MF, Paz MF, Campo E, Colomer D, Novo FJ, Calasanz MJ, Galm O, Guo M, Benitez J et al. 2002 Cancer epigenetics and methylation. Science 297 1807-1808 (discussion 1807-1808). (doi:10.1126/science.297.5588.1807d)

Feinberg AP 2007 Phenotypic plasticity and the epigenetics of human disease. Nature 447 433-440. (doi:10.1038/nature05919)

Feinberg AP \& Vogelstein B 1983 Hypomethylation distinguishes genes of some human cancers from their normal counterparts. Nature 301 89-92. (doi:10.1038/301089a0)

Feinberg AP, Ohlsson R \& Henikoff S 2006 The epigenetic progenitor origin of human cancer. Nature Reviews. Genetics 7 21-33. (doi:10. 1038/nrg1748)

Feldman N, Gerson A, Fang J, Li E, Zhang Y, Shinkai Y, Cedar H \& Bergman Y 2006 G9a-mediated irreversible epigenetic inactivation of Oct-3/4 during early embryogenesis. Nature Cell Biology 8 188-194. (doi:10.1038/ncb1353)

Ferguson AT, Lapidus RG, Baylin SB \& Davidson NE 1995 Demethylation of the estrogen receptor gene in estrogen receptornegative breast cancer cells can reactivate estrogen receptor gene expression. Cancer Research 55 2279-2283.

Fraga MF 2009 Genetic and epigenetic regulation of aging. Current Opinion in Immunology 21 446-453. (doi:10.1016/j.coi.2009.04.003)

Fraga MF, Ballestar E, Paz MF, Ropero S, Setien F, Ballestar ML, HeineSuner D, Cigudosa JC, Urioste M, Benitez J et al. 2005 Epigenetic differences arise during the lifetime of monozygotic twins. PNAS 102 10604-10609. (doi:10.1073/pnas.0500398102)

Fuks F, Burgers WA, Brehm A, Hughes-Davies L \& Kouzarides T 2000 DNA methyltransferase Dnmtl associates with histone deacetylase activity. Nature Genetics 24 88-91. (doi:10.1038/71750)

Fuks F, Burgers WA, Godin N, Kasai M \& Kouzarides T 2001 Dnmt3a binds deacetylases and is recruited by a sequence-specific repressor to silence transcription. EMBO Journal 20 2536-2544. (doi:10.1093/ emboj/20.10.2536)

Garcia-Silva S, Martinez-Iglesias O, Ruiz-Llorente L \& Aranda A 2011 Thyroid hormone receptor betal domains responsible for the antagonism with the ras oncogene: role of corepressors. Oncogene $\mathbf{3 0}$ 854-864. (doi:10.1038/onc.2010.464)

Gardiner-Garden M \& Frommer M 1987 CpG islands in vertebrate genomes. Journal of Molecular Biology 196 261-282. (doi:10.1016/ 0022-2836(87)90689-9)

Guerrero-Bosagna C, Settles M, Lucker B \& Skinner MK 2010 Epigenetic transgenerational actions of vinclozolin on promoter regions of the sperm epigenome. PLoS ONE 5 e13100. (doi:10. 1371/journal.pone.0013100)

Heijmans BT, Tobi EW, Stein AD, Putter H, Blauw GJ, Susser ES, Slagboom PE \& Lumey LH 2008 Persistent epigenetic differences associated with prenatal exposure to famine in humans. PNAS 105 17046-17049. (doi:10.1073/pnas.0806560105)

Holliday R 2006 Epigenetics: a historical overview. Epigenetics 1 76-80. (doi:10.4161/epi.1.2.2762)

Holliday R \& Pugh JE 1975 DNA modification mechanisms and gene activity during development. Science 187 226-232. (doi:10.1126/ science.1111098)

Huang Y, Pastor WA, Shen Y, Tahiliani M, Liu DR \& Rao A 2010 The behaviour of 5-hydroxymethylcytosine in bisulfite sequencing. PLoS ONE 5 e8888. (doi:10.1371/journal.pone.0008888)

Jang ER, Lim SJ, Lee ES, Jeong G, Kim TY, Bang YJ \& Lee JS 2004 The histone deacetylase inhibitor trichostatin A sensitizes estrogen receptor alpha-negative breast cancer cells to tamoxifen. Oncogene 23 1724-1736. (doi:10.1038/sj.onc.1207315) 
Jarrard DF, Kinoshita H, Shi Y, Sandefur C, Hoff D, Meisner LF, Chang C, Herman JG, Isaacs WB \& Nassif N 1998 Methylation of the androgen receptor promoter $\mathrm{CpG}$ island is associated with loss of androgen receptor expression in prostate cancer cells. Cancer Research 58 5310-5314.

Jin SG, Guo C \& Pfeifer GP 2008 GADD45A does not promote DNA demethylation. PLoS Genetics 4 e1000013. (doi:10.1371/journal. pgen.1000013)

Jirtle RL \& Skinner MK 2007 Environmental epigenomics and disease susceptibility. Nature Reviews. Genetics 8 253-262. (doi:10.1038/ nrg2045)

Jones PL, Veenstra GJ, Wade PA, Vermaak D, Kass SU, Landsberger N, Strouboulis J \& Wolffe AP 1998 Methylated DNA and MeCP2 recruit histone deacetylase to repress transcription. Nature Genetics 19 187-191. (doi:10.1038/561)

Juhlin CC, Kiss NB, Villablanca A, Haglund F, Nordenstrom J, Hoog A \& Larsson C 2010 Frequent promoter hypermethylation of the APC and RASSF1A tumour suppressors in parathyroid tumours. PLoS ONE 5 e9472. (doi:10.1371/journal.pone.0009472)

van Kaam KJ, Delvoux B, Romano A, D'Hooghe T, Dunselman GA \& Groothuis PG 2011 Deoxyribonucleic acid methyltransferases and methyl-CpG-binding domain proteins in human endometrium and endometriosis. Fertility and Sterility 95 1421-1427. (doi:10.1016/j. fertnstert.2011.01.031)

Kacem S \& Feil R 2009 Chromatin mechanisms in genomic imprinting. Mammalian Genome 20 544-556. (doi:10.1007/s00335-009-9223-4)

Kafri T, Ariel M, Brandeis M, Shemer R, Urven L, McCarrey J, Cedar H \& Razin A 1992 Developmental pattern of gene-specific DNA methylation in the mouse embryo and germ line. Genes and Development 6 705-714. (doi:10.1101/gad.6.5.705)

Kangaspeska S, Stride B, Metivier R, Polycarpou-Schwarz M, Ibberson D, Carmouche RP, Benes V, Gannon F \& Reid G 2008 Transient cyclical methylation of promoter DNA. Nature 452 112-115. (doi:10. 1038/nature06640)

Kim MS, Kondo T, Takada I, Youn MY, Yamamoto Y, Takahashi S, Matsumoto T, Fujiyama S, Shirode Y, Yamaoka I et al. 2009 DNA demethylation in hormone-induced transcriptional derepression. Nature 461 1007-1012. (doi:10.1038/nature08456)

Kimura H \& Shiota K 2003 Methyl-CpG-binding protein, MeCP2, is a target molecule for maintenance DNA methyltransferase, Dnmt1. Journal of Biological Chemistry 278 4806-4812. (doi:10.1074/jbc. M209923200)

Kondo T, Ezzat S \& Asa SL 2006 Pathogenetic mechanisms in thyroid follicular-cell neoplasia. Nature Reviews. Cancer 6 292-306. (doi:10. $1038 / \mathrm{nrc1836})$

Kondo T, Zheng L, Liu W, Kurebayashi J, Asa SL \& Ezzat S 2007 Epigenetically controlled fibroblast growth factor receptor 2 signaling imposes on the RAS/BRAF/mitogen-activated protein kinase pathway to modulate thyroid cancer progression. Cancer Research 67 5461-5470. (doi:10.1158/0008-5472.CAN-06-4477)

Kouzarides T 2007 Chromatin modifications and their function. Cell 128 693-705. (doi:10.1016/j.cell.2007.02.005)

Kress C, Thomassin H \& Grange T 2006 Active cytosine demethylation triggered by a nuclear receptor involves DNA strand breaks. PNAS 103 11112-11117. (doi:10.1073/pnas.0601793103)

Kriaucionis S \& Heintz N 2009 The nuclear DNA base 5-hydroxymethylcytosine is present in Purkinje neurons and the brain. Science 324 929-930. (doi:10.1126/science.1169786)

Kurian JR, Olesen KM \& Auger AP 2010 Sex differences in epigenetic regulation of the estrogen receptor-alpha promoter within the developing preoptic area. Endocrinology 151 2297-2305. (doi:10 1210/en.2009-0649)

Kuroda A, Rauch TA, Todorov I, Ku HT, Al-Abdullah IH, Kandeel F, Mullen Y, Pfeifer GP \& Ferreri K 2009 Insulin gene expression is regulated by DNA methylation. PLoS ONE 4 e6953. (doi:10.1371/ journal.pone.0006953)

Lalande M 2001 Imprints of disease at GNAS1. Journal of Clinical Investigation 107 793-794. (doi:10.1172/JCI12645)
Lapidus RG, Ferguson AT, Ottaviano YL, Parl FF, Smith HS, Weitzman SA, Baylin SB, Issa JP \& Davidson NE 1996 Methylation of estrogen and progesterone receptor gene $5^{\prime} \mathrm{CpG}$ islands correlates with lack of estrogen and progesterone receptor gene expression in breast tumors. Clinical Cancer Research 2 805-810.

Lee Y, Jin Y, Lim W, Ji S, Choi S, Jang S \& Lee S 2003 A ginsenoside$\mathrm{Rh} 1$, a component of ginseng saponin, activates estrogen receptor in human breast cancer carcinoma MCF-7 cells. Journal of Steroid Biochemistry and Molecular Biology 84 463-468. (doi:10.1016/S09600760(03)00067-0)

Lee RS, Tamashiro KL, Yang X, Purcell RH, Harvey A, Willour VL, Huo Y, Rongione M, Wand GS \& Potash JB 2010 Chronic corticosterone exposure increases expression and decreases deoxyribonucleic acid methylation of Fkbp5 in mice. Endocrinology 151 4332-4343. (doi:10. 1210/en.2010-0225)

Leuenberger N, Pradervand S \& Wahli W 2009 Sumoylated PPARalpha mediates sex-specific gene repression and protects the liver from estrogen-induced toxicity in mice. Journal of Clinical Investigation 119 3138-3148. (doi:10.1172/JCI39019)

Li S, Washburn KA, Moore R, Uno T, Teng C, Newbold RR, McLachlan JA \& Negishi M 1997 Developmental exposure to diethylstilbestrol elicits demethylation of estrogen-responsive lactoferrin gene in mouse uterus. Cancer Research 57 4356-4359.

Li Z, Meng ZH, Chandrasekaran R, Kuo WL, Collins CC, Gray JW \& Dairkee SH 2002 Biallelic inactivation of the thyroid hormone receptor betal gene in early stage breast cancer. Cancer Research 62 1939-1943.

Li S, Hansman R, Newbold R, Davis B, McLachlan JA \& Barrett JC 2003 Neonatal diethylstilbestrol exposure induces persistent elevation of c-fos expression and hypomethylation in its exon- 4 in mouse uterus. Molecular Carcinogenesis 38 78-84. (doi:10.1002/mc.10147)

Li L, Lee KM, Han W, Choi JY, Lee JY, Kang GH, Park SK, Noh DY, Yoo KY \& Kang D 2010 Estrogen and progesterone receptor status affect genome-wide DNA methylation profile in breast cancer. Human Molecular Genetics 19 4273-4277. (doi:10.1093/hmg/ddq351)

Lillycrop KA 2011 Effect of maternal diet on the epigenome: implications for human metabolic disease. Proceedings of the Nutrition Society 70 64-72. (doi:10.1017/S0029665110004027)

Lister R, Pelizzola M, Dowen RH, Hawkins RD, Hon G, Tonti-Filippini J, Nery JR, Lee L, Ye Z, Ngo QM et al. 2009 Human DNA methylomes at base resolution show widespread epigenomic differences. Nature 462 315-322. (doi:10.1038/nature08514)

Martinez-Iglesias O, Garcia-Silva S, Tenbaum SP, Regadera J, Larcher F, Paramio JM, Vennstrom B \& Aranda A 2009 Thyroid hormone receptor betal acts as a potent suppressor of tumor invasiveness and metastasis. Cancer Research 69 501-509. (doi:10.1158/0008-5472. CAN-08-2198)

McCarthy MM 2008 Estradiol and the developing brain. Physiological Reviews 88 91-124. (doi:10.1152/physrev.00010.2007)

McGowan PO, Sasaki A, D'Alessio AC, Dymov S, Labonte B, Szyf M, Turecki G \& Meaney MJ 2009 Epigenetic regulation of the glucocorticoid receptor in human brain associates with childhood abuse. Nature Neuroscience 12 342-348. (doi:10.1038/nn.2270)

Metivier R, Penot G, Hubner MR, Reid G, Brand H, Kos M \& Gannon F 2003 Estrogen receptor-alpha directs ordered, cyclical, and combinatorial recruitment of cofactors on a natural target promoter. Cell 115 751-763. (doi:10.1016/S0092-8674(03)00934-6)

Metivier R, Gallais R, Tiffoche C, Le Peron C, Jurkowska RZ, Carmouche RP, Ibberson D, Barath P, Demay F, Reid G et al. 2008 Cyclical DNA methylation of a transcriptionally active promoter. Nature 452 45-50. (doi:10.1038/nature06544)

Mortusewicz O, Schermelleh L, Walter J, Cardoso MC \& Leonhardt H 2005 Recruitment of DNA methyltransferase I to DNA repair sites. PNAS 102 8905-8909. (doi:10.1073/pnas.0501034102)

Murayama A, Kim MS, Yanagisawa J, Takeyama K \& Kato S 2004 Transrepression by a liganded nuclear receptor via a bHLH activator through co-regulator switching. EMBO Journal 23 1598-1608. (doi:10.1038/sj.emboj.7600157) 
Murgatroyd C, Patchev AV, Wu Y, Micale V, Bockmuhl Y, Fischer D, Holsboer F, Wotjak CT, Almeida OF \& Spengler D 2009 Dynamic DNA methylation programs persistent adverse effects of early-life stress. Nature Neuroscience 12 1559-1566. (doi:10.1038/nn.2436)

Nan X, Ng HH, Johnson CA, Laherty CD, Turner BM, Eisenman RN \& Bird A 1998 Transcriptional repression by the methyl-CpG-binding protein MeCP2 involves a histone deacetylase complex. Nature 393 386-389. (doi:10.1038/30764)

Newbold RR, Hanson RB, Jefferson WN, Bullock BC, Haseman J \& McLachlan JA 1998 Increased tumors but uncompromised fertility in the female descendants of mice exposed developmentally to diethylstilbestrol. Carcinogenesis 19 1655-1663. (doi:10.1093/car$\operatorname{cin} / 19.9 .1655$ )

Newbold RR, Padilla-Banks E \& Jefferson WN 2006 Adverse effects of the model environmental estrogen diethylstilbestrol are transmitted to subsequent generations. Endocrinology 147 S11-S17. (doi:10.1210/en.2005-1164)

Newell-Price J 2003 Proopiomelanocortin gene expression and DNA methylation: implications for Cushing's syndrome and beyond. Journal of Endocrinology 177 365-372. (doi:10.1677/joe.0.1770365)

Newell-Price J, King P \& Clark AJ 2001 The CpG island promoter of the human proopiomelanocortin gene is methylated in nonexpressing normal tissue and tumors and represses expression. Molecular Endocrinology 15 338-348. (doi:10.1210/me.15.2.338)

Ng SF, Lin RC, Laybutt DR, Barres R, Owens JA \& Morris MJ 2010 Chronic high-fat diet in fathers programs beta-cell dysfunction in female rat offspring. Nature 467 963-966. (doi:10.1038/ nature09491)

Ooi SK \& Bestor TH 2008 The colorful history of active DNA demethylation. Cell 133 1145-1148. (doi:10.1016/j.cell.2008.06.009)

Park JH, Stoffers DA, Nicholls RD \& Simmons RA 2008 Development of type 2 diabetes following intrauterine growth retardation in rats is associated with progressive epigenetic silencing of Pdx1. Journal of Clinical Investigation 118 2316-2324. (doi:10.1172/ JCI32011)

Payer B \& Lee JT 2008 X chromosome dosage compensation: how mammals keep the balance. Annual Review of Genetics 42 733-772. (doi:10.1146/annurev.genet.42.110807.091711)

Prins GS 2008 Estrogen imprinting: when your epigenetic memories come back to haunt you. Endocrinology 149 5919-5921. (doi:10. 1210/en.2008-1266)

Rai K, Huggins IJ, James SR, Karpf AR, Jones DA \& Cairns BR 2008 DNA demethylation in zebrafish involves the coupling of a deaminase, a glycosylase, and gadd45. Cell 135 1201-1212. (doi:10. 1016/j.cell.2008.11.042)

Rai K, Sarkar S, Broadbent TJ, Voas M, Grossmann KF, Nadauld LD, Dehghanizadeh S, Hagos FT, Li Y, Toth RK et al. 2010 DNA demethylase activity maintains intestinal cells in an undifferentiated state following loss of APC. Cell 142 930-942. (doi:10.1016/j.cell. 2010.08.030)

Reid G, Gallais R \& Metivier R 2009 Marking time: the dynamic role of chromatin and covalent modification in transcription. International Journal of Biochemistry E Cell Biology 41 155-163. (doi:10.1016/j. biocel.2008.08.028)

Renner R 2009 Key environmental epigenetics paper challenged. Environmental Science EO Technology 43 8009-8010. (doi:10.1021/ es902777p)

Revill K, Dudley KJ, Clayton RN, McNicol AM \& Farrell WE 2009 Loss of neuronatin expression is associated with promoter hypermethylation in pituitary adenoma. Endocrine-Related Cancer 16 537-548. (doi:10.1677/ERC-09-0008)

Robertson KD 2005 DNA methylation and human disease. Nature Reviews. Genetics 6 597-610. (doi:10.1038/nrg1655)

Robertson KD, Ait-Si-Ali S, Yokochi T, Wade PA, Jones PL \& Wolffe AP 2000 DNMT1 forms a complex with Rb, E2F1 and HDAC1 and represses transcription from E2F-responsive promoters. Nature Genetics 25 338-342. (doi:10.1038/77124)
Rountree MR, Bachman KE \& Baylin SB 2000 DNMT1 binds HDAC2 and a new co-repressor, DMAP1, to form a complex at replication foci. Nature Genetics 25 269-277. (doi:10.1038/77023)

Sandovici I, Smith NH, Nitert MD, Ackers-Johnson M, Uribe-Lewis S, Ito Y, Jones RH, Marquez VE, Cairns W, Tadayyon M et al. 2011 Maternal diet and aging alter the epigenetic control of a promoter-enhancer interaction at the Hnf4a gene in rat pancreatic islets. PNAS 108 5449-5454. (doi:10.1073/pnas. 1019007108)

Sasaki M, Kaneuchi M, Fujimoto S, Tanaka Y \& Dahiya R 2003 Hypermethylation can selectively silence multiple promoters of steroid receptors in cancers. Molecular and Cellular Endocrinology 202 201-207. (doi:10.1016/S0303-7207(03)00084-4)

Schmitt AM, Schmid S, Rudolph T, Anlauf M, Prinz C, Kloppel G, Moch H, Heitz PU, Komminoth P \& Perren A 2009 VHL inactivation is an important pathway for the development of malignant sporadic pancreatic endocrine tumors. Endocrine-Related Cancer 16 1219-1227. (doi:10.1677/ERC-08-0297)

Schwarz JM, Nugent BM \& McCarthy MM 2010 Developmental and hormone-induced epigenetic changes to estrogen and progesterone receptor genes in brain are dynamic across the life span. Endocrinology 151 4871-4881. (doi:10.1210/en.20100142)

Shafiei F, Rahnama F, Pawella L, Mitchell MD, Gluckman PD \& Lobie PE 2008 DNMT3A and DNMT3B mediate autocrine hGH repression of plakoglobin gene transcription and consequent phenotypic conversion of mammary carcinoma cells. Oncogene 27 2602-2612. (doi:10.1038/sj.onc.1210917)

Simpson DJ, Hibberts NA, McNicol AM, Clayton RN \& Farrell WE 2000 Loss of $\mathrm{pRb}$ expression in pituitary adenomas is associated with methylation of the RB1 CpG island. Cancer Research 60 1211-1216.

Skinner MK, Manikkam M \& Guerrero-Bosagna C 2010 Epigenetic transgenerational actions of environmental factors in disease etiology. Trends in Endocrinology and Metabolism 21 214-222. (doi:10. 1016/j.tem.2009.12.007)

Stein CE, Fall CH, Kumaran K, Osmond C, Cox V \& Barker DJ 1996 Fetal growth and coronary heart disease in south India. Lancet 348 1269-1273. (doi:10.1016/S0140-6736(96)04547-3)

Stidley CA, Picchi MA, Leng S, Willink R, Crowell RE, Flores KG, Kang H, Byers T, Gilliland FD \& Belinsky SA 2010 Multivitamins, folate, and green vegetables protect against gene promoter methylation in the aerodigestive tract of smokers. Cancer Research 70 569-574. (doi:10.1158/0008-5472.CAN-09-3410)

Sui L \& Li BM 2010 Effects of perinatal hypothyroidism on regulation of reelin and brain-derived neurotrophic factor gene expression in rat hippocampus: role of DNA methylation and histone acetylation. Steroids 75 988-997. (doi:10.1016/j.steroids. 2010.06.005)

Tang WY, Newbold R, Mardilovich K, Jefferson W, Cheng RY, Medvedovic M \& Ho SM 2008 Persistent hypomethylation in the promoter of nucleosomal binding protein 1 (Nsbp1) correlates with overexpression of Nsbpl in mouse uteri neonatally exposed to diethylstilbestrol or genistein. Endocrinology 149 5922-5931. (doi:10. 1210/en.2008-0682)

Thompson RF, Fazzari MJ, Niu H, Barzilai N, Simmons RA \& Greally JM 2010 Experimental intrauterine growth restriction induces alterations in DNA methylation and gene expression in pancreatic islets of rats. Journal of Biological Chemistry 285 15111-15118. (doi:10. 1074/jbc.M109.095133)

Turner BM 1998 Histone acetylation as an epigenetic determinant of long-term transcriptional competence. Cellular and Molecular Life Sciences 54 21-31. (doi:10.1007/s000180050122)

Waddington C 1942 The epigenotype. Endeavour 1 18-20.

Weaver IC, D'Alessio AC, Brown SE, Hellstrom IC, Dymov S, Sharma S, Szyf M \& Meaney MJ 2007 The transcription factor nerve growth factor-inducible protein a mediates epigenetic programming: 
altering epigenetic marks by immediate-early genes. Journal of Neuroscience 27 1756-1768. (doi:10.1523/JNEUROSCI.4164-06. 2007)

Whitaker RC, Wright JA, Pepe MS, Seidel KD \& Dietz WH 1997 Predicting obesity in young adulthood from childhood and parental obesity. New England Journal of Medicine 337 869-873. (doi:10.1056/NEJM199709253371301)

Wu Y, Strawn E, Basir Z, Halverson G \& Guo SW 2007 Aberrant expression of deoxyribonucleic acid methyltransferases DNMT1, DNMT3A, and DNMT3B in women with endometriosis. Fertility and Sterility 87 24-32. (doi:10.1016/j.fertnstert.2006. 05.077)

Xing M 2007 Gene methylation in thyroid tumorigenesis. Endocrinology 148 948-953. (doi:10.1210/en.2006-0927)

Yamagata Y, Asada H, Tamura I, Lee L, Maekawa R, Taniguchi K, Taketani T, Matsuoka A, Tamura H \& Sugino N 2009 DNA methyltransferase expression in the human endometrium: downregulation by progesterone and estrogen. Human Reproduction $\mathbf{2 4}$ 1126-1132. (doi:10.1093/humrep/dep015)

Yoon HG, Chan DW, Reynolds AB, Qin J \& Wong J 2003 N-CoR mediates DNA methylation-dependent repression through a methyl CpG binding protein Kaiso. Molecular Cell 12 723-734. (doi:10. 1016/j.molcel.2003.08.008)

Zhao Z, Fan L \& Frick KM 2010 Epigenetic alterations regulate estradiol-induced enhancement of memory consolidation. PNAS 107 5605-5610. (doi:10.1073/pnas.0910578107)

Received in final form 6 July 2011

Accepted 28 July 2011

Made available online as an Accepted Preprint 29 July 2011 